\title{
Original Article Solidification/Stabilization of Arsenic in Red Mud upon Addition of Fe (III) or Fe (III) and Al (III) Dissolved in $\mathrm{H}_{2} \mathrm{SO}_{4}$
}

\author{
Dazhong Yang, Atsushi Sasaki, Masatoshi Endo \\ Chemistry and Chemical Engineering, Yamagata University, Yonezawa, Yamagata, Japan
}

\begin{abstract}
In the aluminum industry, as an alkaline waste, red mud is composed of Fe and Al. It is difficult to safely dispose certain types of some arsenic-containing red mud owing to hazardous arsenic leaching. Hence, the method of arsenic stabilization using $\mathrm{Fe}$ (III) or $\mathrm{H}_{2} \mathrm{SO}_{4}$ to reduce arsenic leaching from red mud was investigated. The results indicated that the addition of $3-5 \% \mathrm{Fe}_{2}\left(\mathrm{SO}_{4}\right)_{3}$ or $\mathrm{H}_{2} \mathrm{SO}_{4}$ (ratio of $\mathrm{H}^{+}(\mathrm{mM}) /$ red mud $\left.(\mathrm{g}) \approx 1.5\right)$ into red mud and maintaining the $\mathrm{pH}$ at 4 until dryness was achieved at room temperature, decreased arsenic solubility from 360 to $2-6 \mu \mathrm{g} / \mathrm{L}(<10 \mu \mathrm{g} / \mathrm{L}$ : Environmental criteria in Japan) and maintained the same for several months. In the mechanism of arsenic stabilization, $\mathrm{Fe}^{3+}$ ions added or $\mathrm{Fe}^{3+}$ and $\mathrm{Al}^{3+}$ ions dissolved from red mud by adding $\mathrm{H}_{2} \mathrm{SO}_{4}$ reacted with arsenic and formed insoluble Fe-As and Al-As compounds. Through X-ray diffraction analysis, insoluble arsenic compounds including iron arsenate, iron hydrogen arsenate, aluminum arsenate, and aluminum arsenate hydrate were detected and considered as responsible for low arsenic leaching. Additionally, the results suggested that $\mathrm{HCl}$ was not appropriate for stabilizing arsenic in red mud because the high amounts of $\mathrm{Cl}^{-}$negatively influence the formation of insoluble arsenic compounds.
\end{abstract}

Keywords: solidification/stabilization of arsenic, red mud, $\mathrm{Fe}$ (III) Al ions, $\mathrm{H}_{2} \mathrm{SO}_{4}$

\section{INTRODUCTION}

Red mud as a bauxite residue is produced in alumina plants by the Bayer process in which Al-containing minerals are dissolved in hot $\mathrm{NaOH}$ solution to extract Al. Globally, approximately 120 million $\mathrm{t}$ of red mud are annually produced, and the global total discharged amount exceeded more than 3.5 billion $\mathrm{t}$ in 2014 [1]. Typically, the chemical properties of red mud include high alkalinity $(\mathrm{pH}=9.7-12.8)$, elevated salinity, and elevated concentrations of $\mathrm{Al}$ and Fe.

Red mud is a naturally occurring heterogeneous material that is mainly composed of one or several aluminum hydroxide minerals, including primarily gibbsite $\left[\mathrm{Al}(\mathrm{OH})_{3}\right]$, boehmite $[\gamma-\mathrm{AlO}(\mathrm{OH})]$, and diaspore $[\alpha-\mathrm{AlO}(\mathrm{OH})]$. Except these aluminum hydroxide minerals (Average wt.\%: $26-$ 60 ), most red mud is also rich in oxides of Fe (Average wt.\%: 10 - 35), Ti (Average wt.\%: 2 - 4), Si (Average wt.\%: 4 - 8), and some special elements such as $\mathrm{Zn}, \mathrm{Ni}$, and V [2-4]. With the exception of inherent high alkalinity, the leakage risk of toxic elements from red mud could also limit its reclamation and application, such as potentially toxic metals and metalloids: As, Cr, Ni, Pb, and Mo [5, 6]. In Minas Gerais State, Brazil, the red mud had an arsenic content of $19.3 \mathrm{mg} / \mathrm{kg}$ [7]. In Ajka, Hungary, red mud samples contained elevated concentrations $(150 \mathrm{mg} / \mathrm{kg})$ of potentially toxic arsenic (As). And in aqueous solution, Ajka red mud had dissolved As concentrations of $4-6 \mathrm{mg} / \mathrm{L}$ [8-10]. Many studies examine As due to its potential harmful effect on human health. Permanent As intake leads to chronic intoxication, and prolonged As exposure can damage the central nervous system, liver, and skin and results in the appearance of diverse types of cancers such as hyperkeratosis, lung, and skin cancer [11]. A wide range of studies related to As removal were conducted to reduce the risk that underwater As contamination poses to human health. Currently, several treatment methods such as adsorption, ion exchange, reverse osmosis, nanofiltration, coprecipitation, membrane distillation, and biological procedures are increasingly used for the removal of As [12-15]. Among these researches, the sorption and coprecipitation of As by Fe (II / III) compounds were widely conducted. The 
main mechanisms of these include the adsorption of arsenate via surface complex on iron oxides (hematite goethite) and ferrihydrite mainly as an inner-sphere bidentate complex [16-19] and the formation of insoluble Fe-As compounds, ferric arsenate, scorodite and poorly crystalline ferric arsenate [20-22]. Additionally, Al ions, hydroxide and oxide of aluminum also showed good behaviors in adsorbing arsenic as well as Fe [23, 24].

The aims of the study involved decreasing the high alkalinity, reducing As leaching concentration from red mud (less than 10 ppb, satisfying Environment Agency Notification No.18 in Japan) and making this red mud safely usable. Given the effective As stabilization by Fe and to decrease the high $\mathrm{pH}$ of red mud, Fe ions were added into red mud to control As leaching concentration. And given that the main components of red mud were $\mathrm{Fe}$ and $\mathrm{Al}$, inorganic acid was used to release $\mathrm{Fe}$ and $\mathrm{Al}$ ions and decrease the $\mathrm{pH}$ of red mud. In the experiments, additive amounts of an Fe reagent and inorganic acids, $\mathrm{pH}$ variation of the disposed red mud, and the long-term effect of As stabilization were investigated to optimize the reaction conditions. Moreover, the study also examined the mechanism of solidification/stabilization of As in red mud with the addition of Fe (III) or inorganic acids.

\section{MATERIALS AND METHODS}

\section{Materials and analytical instruments}

As-containing red mud was supplied by an aluminum company. Several million tons of the red mud were in the final disposal site for several decades. A Ferric Sulfate solution (assay as $\mathrm{Fe}_{2}\left(\mathrm{SO}_{4}\right)_{3}: 64 \%$ ) was supplied by JUJO Synthetic Chemistry Labo, Tokyo Japan. Additionally, $\mathrm{FeSO}_{4} \cdot 7 \mathrm{H}_{2} \mathrm{O}$ (assay as $\mathrm{FeSO}_{4}$ : 55\%) was provided by Wako Pure Chemical Industries, Ltd., Osaka Japan. It was considered that ferrous in solution was oxidized easily in air, so to avoid the influence of oxidization, $\mathrm{FeSO}_{4}$ was used as solid. The proportion of additive amounts used in subsequent experiments, namely Ferric Sulfate solution and $\mathrm{FeSO}_{4} \cdot 7 \mathrm{H}_{2} \mathrm{O}$, were calculated as $\mathrm{Fe}_{2}\left(\mathrm{SO}_{4}\right)_{3}$ and $\mathrm{FeSO}_{4}$. For example, the use of $5 \% \mathrm{Fe}_{2}\left(\mathrm{SO}_{4}\right)_{3}$ or $\mathrm{FeSO}_{4}$ to dispose $1.0 \mathrm{~g}$ red mud indicated that the actual additive amount corresponds to $0.078 \mathrm{~mL}$ Ferric Sulfate solution or $0.091 \mathrm{~g} \mathrm{FeSO}_{4} \cdot 7 \mathrm{H}_{2} \mathrm{O}$. All chemicals were of analytical grade and used without further purification. Deionized (DI) water was used for all the experiments. All glassware were cleaned by soaking in $5 \% \mathrm{HNO}_{3}$ and rinsed thrice with DI water prior to use.

The concentration of As in the solution was determined using an atomic absorption spectrophotometer (AA7000,
Shimadzu Corporation, Kyoto, Japan) and a hydride generator (Shimadzu Corporation). The detection limit of the instrument corresponded to $0.1 \mu \mathrm{g} / \mathrm{L}$. A solution containing $0.4 \% \mathrm{NaBH}_{4}$ and $0.5 \% \mathrm{NaOH}$ was mixed with $15 \% \mathrm{HCl}$ to generate hydride. Prior to the analyses, a sample solution was mixed with a solution ( $20 \%$ potassium iodide) and ( $10 \%$ concentrated hydrochloric acid) at volume proportion of 8:1:1 for the reduction from As (V) to As (III). Finally, As (III) in solution was reacted with a hydride to form a hydride of As, which was directly determined by AAS.

Solid samples were characterized using an Ultima IV X-ray diffractometer (Rigaku Corporation, Tokyo, Japan) that was equipped with a copper target and a D/tex Ultra detector. The equipment was operated at $40 \mathrm{kV}$ and $40 \mathrm{~mA}$ by step scanning from $10^{\circ}$ to $80^{\circ}$ in increments of $0.02^{\circ} 2 \theta$. Integrated X-ray powder diffraction software was used in the analysis. The shapes of the surface of the solid samples were analyzed on a SU8000 (Hitachi Corporation, Tokyo, Japan) scanning electron microscope. All the samples were imaged at $5 \mathrm{kV}$. Compositions of red mud were determined using a SU8000 (Hitachi Corporation) energy dispersive X-ray spectrometer at $20 \mathrm{kV}$.

\section{Composition of red mud}

Red mud was dried at $70^{\circ} \mathrm{C}$ for $3 \mathrm{~h}$ to calculate the moisture content and dried red mud was sieved (with an approximate particle size corresponding to $0.149 \mathrm{~mm}$ ) and analyzed by X-ray diffraction (XRD) and Energy Dispersive X-ray (EDX) to characterize the mineralogical characteristics and composition, respectively.

\section{Arsenic content test}

Dried red mud (7.50 g) was mixed with $250 \mathrm{~mL}$ of $1 \mathrm{M} \mathrm{HCl}$ and shaken for $2 \mathrm{~h}$ using a shaker (SA 300, Yamato, Tokyo, Japan). The leachate was filtered using a $0.45-\mu \mathrm{m}$ membrane, and the As concentration was determined by atomic absorption spectrophotometer (AAS). The As content in red mud was calculated based on the As concentration [25].

\section{Arsenic leaching test}

Red mud sample (10.0 g) was mixed with $100 \mathrm{~mL}$ pure water and shaken for $6 \mathrm{~h}$. After a centrifugal separation, the leachate was filtered using a $0.45-\mu \mathrm{m}$ membrane, and the $\mathrm{pH}$ value was measured. Arsenic concentration in the leachate was analyzed using hydride generator and atomic absorption spectrophotometer (HG-AAS), and this was considered as corresponding to the As leaching concentration from red mud [26]. 
Stabilization of arsenic in red mud by Fe (II/III) ions Stabilization test

Red mud was mixed with Ferric Sulfate solution or $\mathrm{FeSO}_{4} \cdot 7 \mathrm{H}_{2} \mathrm{O}$ by iron spoon with hand, and the $\mathrm{pH}$ of the mixture was measured by the $\mathrm{pH}$ test paper. The red mud was placed at room temperature for $24 \mathrm{~h}$ to dry, and the samples were analyzed by Scanning Electron Microscopy (SEM). Arsenic concentration and $\mathrm{pH}$ of leachate was determined in the leaching test. In a few experiments, cement (cement number: Pacific S-GS211 marked as C in later statement) and pieces of old newspapers $\left(0.1-0.3 \mathrm{~cm}^{2}\right.$; marked as $\mathrm{P}$ in later statement) were also added into red mud with Fe reagents to enhance the strength of the red mud.

\section{Simulation test}

In order to investigate the stable As compounds potentially generated in the above operations, $5 \mathrm{~mL} \mathrm{As}^{5+}$ solution $\left(\mathrm{Na}_{2} \mathrm{HAsO}_{4} \cdot 7 \mathrm{H}_{2} \mathrm{O} 0.15 \mathrm{~g}\right)$ and $5 \mathrm{~mL} \mathrm{Fe}{ }^{3+}$ solution $\left(\mathrm{Fe}_{2}\left(\mathrm{SO}_{4}\right)_{3}\right.$ $1.92 \mathrm{~g}$ ) were mixed, and the $\mathrm{pH}$ was adjusted to 4 using $\mathrm{NaOH}$ solution. The solution $\left(\mathrm{Fe}^{3+}: \mathrm{As}^{5+}=20: 1\right)$ was placed in room temperature for $6 \mathrm{~h}$, and filtration was performed. The resultant product was dried at $70^{\circ} \mathrm{C}$ for $12 \mathrm{~h}$ and examined through XRD analysis.

Stabilization of arsenic in red mud by inorganic acids $\left(\mathrm{H}_{2} \mathrm{SO}_{4}, \mathrm{HCl}\right)$

pH adjustment test

In order to verify the relationship between $\mathrm{pH}$ of leachate and As adsorption by red mud, $2.0 \mathrm{~g}$ red mud and $20 \mathrm{~mL}$ pure water were mixed, and the $\mathrm{pH}$ of the solution was changed from 3 to 10 by using $\mathrm{HCl}$. These samples were tumbled in a shaker for $6 \mathrm{~h}$. Arsenic leaching concentration and the $\mathrm{pH}$ of the leachate was determined.

\section{Stabilization Test}

Red mud was mixed with a certain amount of $\mathrm{H}_{2} \mathrm{SO}_{4}$ or $\mathrm{HCl}$ and the $\mathrm{pH}$ of the mixture was then measured. The red mud was placed at room temperature for $24 \mathrm{~h}$ to dry, and the samples were analyzed by SEM. Arsenic concentration and the $\mathrm{pH}$ of the leachate was determined in the leaching test.

\section{Simulation Test}

To examine the stable As compounds potentially generated in the forementioned operations in which $\mathrm{H}_{2} \mathrm{SO}_{4}$ was added, $5 \mathrm{~mL} \mathrm{As}{ }^{5+}$ solution $\left(\mathrm{Na}_{2} \mathrm{HAsO}_{4} \cdot 7 \mathrm{H}_{2} \mathrm{O} 0.15 \mathrm{~g}\right), 5 \mathrm{~mL}$ $\mathrm{Fe}^{3+}$, and $\mathrm{Al}^{3+}$ solution $\left(\mathrm{Fe}_{2}\left(\mathrm{SO}_{4}\right)_{3} 0.96 \mathrm{~g} ; \mathrm{Al}_{2}\left(\mathrm{SO}_{4}\right)_{3} 0.82 \mathrm{~g}\right.$ ; $\mathrm{Na}_{2} \mathrm{SO}_{4} 0.2272 \mathrm{~g}$ ) were mixed and the $\mathrm{pH}$ was adjusted to 4 using $\mathrm{NaOH}$ solution. The solution $\left(\mathrm{SO}_{4}{ }^{2-}: \mathrm{Fe}^{3+}: \mathrm{Al}^{3+}\right.$ :
$\left.\mathrm{As}^{5+}=33: 10: 10: 1\right)$ was mixed for 20 min and filtration was performed. Furthermore, in the simulation test in which $\mathrm{HCl}$ was added, $5 \mathrm{~mL} \mathrm{As}{ }^{5+}$ solution $\left(\mathrm{Na}_{2} \mathrm{HAsO}_{4} \cdot 7 \mathrm{H}_{2} \mathrm{O}\right.$ $0.15 \mathrm{~g}), 5 \mathrm{~mL} \mathrm{Fe}^{3+}$, and $\mathrm{Al}^{3+}$ solution $\left(\mathrm{FeCl}_{3} \cdot 6 \mathrm{H}_{2} \mathrm{O} 1.29 \mathrm{~g}\right.$; $\mathrm{AlCl}_{3} \cdot 6 \mathrm{H}_{2} \mathrm{O} 1.16 \mathrm{~g} ; \mathrm{NaCl} 0.19 \mathrm{~g}$ ) were mixed and the $\mathrm{pH}$ was adjusted to 4 using $\mathrm{NaOH}$ solution. The solution $\left(\mathrm{Cl}^{-}: \mathrm{Fe}^{3+}\right.$ : $\left.\mathrm{Al}^{3+}: \mathrm{As}^{5+}=66: 10: 10: 1\right)$ was mixed for $20 \mathrm{~min}$ and filtration was performed. The two types of resultants were dried at $70^{\circ} \mathrm{C}$ for $12 \mathrm{~h}$ and examined through XRD analysis. In the experiment, $\mathrm{SO}_{4}{ }^{2-}$ and $\mathrm{Cl}^{-}$concentrations were calculated based on the actual added amounts of $\mathrm{H}_{2} \mathrm{SO}_{4}$ and $\mathrm{HCl}$ in the red mud.

\section{Long-term stability test}

The red mud disposed by $3 \%$ and $5 \% \mathrm{Fe}_{2}\left(\mathrm{SO}_{4}\right)_{3}$ and inorganic acids $\left(\mathrm{H}_{2} \mathrm{SO}_{4}, \mathrm{HCl}\right)$ with a ratio of $\mathrm{H}^{+}(\mathrm{mM}) /$ red mud (g) corresponding to $1.5 \mathrm{mM} / \mathrm{g}$ were exposed to air for durations corresponding to $15,30,60$ and $90 \mathrm{~d}$. Arsenic leaching concentrations were determined in this period. After disposal, the samples were analyzed using SEM to compare the changes in surface structure prior to disposal.

\section{RESULTS AND DISCUSSION}

\section{Composition of Red Mud}

The moisture content of the red mud was determined as $20 \%$, and the $\mathrm{pH}$ corresponded to 12 . The proportion of elements is listed in Table 1. Specifically, Fe, Al, and O occupied a large proportion in the red mud. The XRD analysis (not shown in the study) indicated that the main components of the red mud corresponded to hematite $\left(\mathrm{Fe}_{1.67} \mathrm{H}_{0.99} \mathrm{O}_{3}\right)$, aluminum oxide $\left(\mathrm{Al}_{2} \mathrm{O}_{3}\right)$, and a large amount of amorphous substances that were mainly composed of iron oxide hydroxide $(\mathrm{FeOOH})$ and aluminum hydroxide oxide

Table 1 Elemental composition of the red mud.

\begin{tabular}{cc}
\hline \hline Elements & Concentration of atoms [\%] \\
\hline $\mathrm{O}$ & 65.29 \\
$\mathrm{Fe}$ & 9.82 \\
$\mathrm{Al}$ & 9.18 \\
$\mathrm{Na}$ & 7.66 \\
$\mathrm{Si}$ & 5.56 \\
$\mathrm{Ti}$ & 1.33 \\
$\mathrm{Ca}$ & 0.9 \\
$\mathrm{Cl}$ & 0.14 \\
$\mathrm{~S}$ & 0.12 \\
$\mathrm{As}$ & 0.01 \\
\hline
\end{tabular}


Table 2 Arsenic leaching concentrations at the stabilization test with the addition of Fe (II/III) ions.

\begin{tabular}{|c|c|c|c|}
\hline NO. & Matrices Composition & Arsenic leaching [ppb] & $\mathrm{pH}$ of leachate $[-$ \\
\hline 1 & Red mud & 360.0 & 10.0 \\
\hline 2 & Red mud $+3.0 \% \mathrm{Fe}\left(\mathrm{NO}_{3}\right)_{3}$ & 7.5 & 7.5 \\
\hline 3 & Red mud $+1.5 \% \mathrm{Fe}_{2}\left(\mathrm{SO}_{4}\right)_{3}$ & 16.2 & 7.7 \\
\hline 4 & Red mud $+3.0 \% \mathrm{Fe}_{2}\left(\mathrm{SO}_{4}\right)_{3}$ & 7.4 & 7.2 \\
\hline 5 & Red mud $+5.0 \% \mathrm{Fe}_{2}\left(\mathrm{SO}_{4}\right)_{3}$ & 4.2 & 6.6 \\
\hline 6 & Red mud $+1.5 \% \mathrm{FeSO}_{4}$ & 14.0 & 8.2 \\
\hline 7 & $\mathrm{Red}$ mud $+3.0 \% \mathrm{FeSO}_{4}$ & 6.8 & 7.0 \\
\hline 8 & Red mud $+5.0 \% \mathrm{FeSO}_{4}$ & 6.2 & 6.5 \\
\hline 9 & Red mud $+3.0 \% \mathrm{C}+3 \% \mathrm{P}$ & 14.2 & 11.4 \\
\hline 10 & Red mud $+1.5 \% \mathrm{Fe}_{2}\left(\mathrm{SO}_{4}\right)_{3}+3 \% \mathrm{C}+3 \% \mathrm{P}$ & 10.4 & 8.8 \\
\hline 11 & Red mud $+3.0 \% \mathrm{Fe}_{2}\left(\mathrm{SO}_{4}\right)_{3}+3 \% \mathrm{C}+3 \% \mathrm{P}$ & 6.2 & 8.5 \\
\hline 12 & Red mud $+5.0 \% \mathrm{Fe}_{2}\left(\mathrm{SO}_{4}\right)_{3}+3 \% \mathrm{C}+3 \% \mathrm{P}$ & 6.8 & 8.1 \\
\hline 13 & Red mud $+1.5 \% \mathrm{FeSO}_{4}+3 \% \mathrm{C}+3 \% \mathrm{P}$ & 28.7 & 8.6 \\
\hline 14 & Red mud $+3.0 \% \mathrm{FeSO}_{4}+3 \% \mathrm{C}+3 \% \mathrm{P}$ & 12.3 & 8.5 \\
\hline 15 & Red mud $+5.0 \% \mathrm{FeSO}_{4}+3 \% \mathrm{C}+3 \% \mathrm{P}$ & 11.7 & 8.2 \\
\hline
\end{tabular}

C: Cement P: Old newspapers $\left(0.1-0.3 \mathrm{~cm}^{2}\right)$

$(\mathrm{AlO}(\mathrm{OH}))$ at the specific high $\mathrm{pH}$. The total content of As in red mud approximately corresponded to $27.5 \mathrm{mg} / \mathrm{kg}$. In the leaching test, the concentration of As leaching from red mud approximately corresponded to $360 \mathrm{ppb}$, which significantly exceeded the upper limit $(10 \mu \mathrm{g} / \mathrm{L})$ described in Japan Environment Agency Notification 18. The As (V) in the high $\mathrm{pH}$ condition mainly existed as $\mathrm{AsO}_{3}{ }^{-}$and $\mathrm{AsO}_{4}{ }^{3-}$ species, and $\mathrm{As}$ (III) may occur as both $\mathrm{AsO}_{2}{ }^{-}$and $\mathrm{AsO}_{3}{ }^{3-}$ species [27]. Soluble As compounds, namely iron arsenic (FeAs), svenekite $\left(\mathrm{Ca}\left(\mathrm{H}_{2} \mathrm{AsO}_{4}\right)_{2}\right)$, and calcium arsenide $(\mathrm{CaAs})$, were also detected in red mud by XRD analysis. Svenekite is a soluble compound that is reported in extant studies [28], and iron arsenic and calcium arsenide are unstable in water. The forementioned compounds are considered as the main source of As leaching.

\section{Stabilization of Arsenic in Red Mud by adding Fe (II/III) ions}

Red mud was disposed by Fe (II/III) reagents as described above. Arsenic leaching concentrations are listed in Table 2. In this case, As leaching decreased to approximately 4-7 ppb (Table 2, No-4,5,7,8) with the addition of Fe (II/ III) ions, and this was less than the upper limit $(10 \mu \mathrm{g} / \mathrm{L})$ of environmental criteria in Japan with respect to As leaching concentration. When red mud was mixed with Fe reagents, the $\mathrm{pH}$ of the mixture approximately corresponded to $4-5$. Additionally, the $\mathrm{pH}$ of leachate changed from 10 to approximately $6-8$. There were various reasons for the stabilization of As with the addition of Fe (II/III) ions. First, the added $\mathrm{Fe}$ (II/III) ions reacted with As to form some insoluble $\mathrm{Fe}-$ As compounds such as poorly crystallized ferric arsenate. Furthermore, $\mathrm{Fe}_{1.67} \mathrm{H}_{0.99} \mathrm{O}_{3}, \mathrm{Al}_{2} \mathrm{O}_{3}, \mathrm{FeOOH}$, and $\mathrm{AlO}(\mathrm{OH})$ in the red mud were unable to adequately adsorb As in an alkali condition with respect to the surfaces of adsorbents prior to the addition of $\mathrm{Fe}$ (II/III) ions. The As ions were both negative and coulombic repulsions between the negatively charged ion and negatively charged surface significantly decreased the arsenate adsorption rate [29]. The added ferric and ferrous ions consumed $\mathrm{OH}^{-}$and generated ferric/ferrous hydroxide and ferrihydrite. This decreased the $\mathrm{pH}$ of the red mud and promoted the adsorption of As by the red mud itself. Moreover, the newly generated ferric/ferrous hydroxide and ferrihydrite fixed more As by coprecipitation.

When cement (C) and old newspapers (P) were added to the system, the alkaline cement increased the $\mathrm{pH}$ of the red mixture. The $\mathrm{C}$ and $\mathrm{P}$ did not affect the ferric with respect to stabilizing As (as shown by the comparison of No-4,5 and 11,12 in Table 2). However, with respect to ferrous ions, As leaching increased from approximately $6-7$ to approximately $12 \mathrm{ppb}$ (as shown by the comparison of No-7,8 and 14,15 in Table 2). This suggested that ferric exhibited a stronger reaction capacity of stabilizing As when compared to that of ferrous in this case, and thus ferrous ions were more sensitive than ferric ions to the $\mathrm{pH}$ influence. This is potentially because hydrolysis of ferric was stronger than ferrous, and $\mathrm{Fe}^{3+}$ could consume more $\mathrm{OH}^{-}$and exist in the red mud 
to stabilize As. However, in an alkali condition, most $\mathrm{Fe}^{2+}$ quickly changed into $\mathrm{Fe}(\mathrm{OH})_{2}$, and only a low amount of $\mathrm{Fe}^{2+}$ reacted with As. Therefore, it is better to use $\mathrm{Fe}^{3+}$ than $\mathrm{Fe}^{2+}$ to dispose the red mud in this case. In air, a few white or transparent crystals also appeared in the surface of red mud, which is discussed in a later section.

\section{Stabilization of Arsenic in the Red Mud by Inor- ganic Acids}

The results confirmed that high alkali condition did not contribute to the adsorption of As on oxide or hydroxide of Fe/Al that largely existed in the red mud. The results of the $\mathrm{pH}$ adjustment test are shown in Fig. 1. The variation trend of As leaching suggested that As adsorption by red mud itself was highly $\mathrm{pH}$ dependent. In both low and high $\mathrm{pH}$ conditions, As was not adequately adsorbed by the red mud. However, at a leachate $\mathrm{pH}$ near 5, the As concentration decreased to $10 \mathrm{ppb}$, and this suggested that oxide or hydroxide of $\mathrm{Fe} / \mathrm{Al}$ in red mud exhibited a strong adsorption capacity of As in a weakly acidic condition.

As shown in Fig. 1, slight changes in the leachate $\mathrm{pH}$ significantly changed the As concentration, and this indicated that the adsorption was not so stable. Despite this, it was more advantageous to clearly maintain the $\mathrm{pH}$ of the system as weakly acidic or neutral to reduce As leaching. When the $\mathrm{pH}$ decreased, a low amount of $\mathrm{Fe}$ and $\mathrm{Al}$ ions were also released from the red mud, and this is considered as helpful in the stabilization of As.

Furthermore, $\mathrm{H}_{2} \mathrm{SO}_{4}$ and $\mathrm{HCl}$ were added into the red mud to decrease the $\mathrm{pH}$ of red mud to weakly acidic or neutral and release additional $\mathrm{Fe}$ and $\mathrm{Al}$ ions to stabilize the arsenic (Table 3). The results revealed that excess acids could increase the dissolution of As. When the ratio of $\mathrm{H}^{+}(\mathrm{mM})$ and red mud (g) approximately corresponded to $1.5 \mathrm{mM} / \mathrm{g}$ (Fig. 2), the $\mathrm{pH}$ of mixture was maintained at 4 , and arsenic leaching was approximately limited to $1.6 \mathrm{ppb}\left(\right.$ by $\left.\mathrm{H}_{2} \mathrm{SO}_{4}\right)$ and

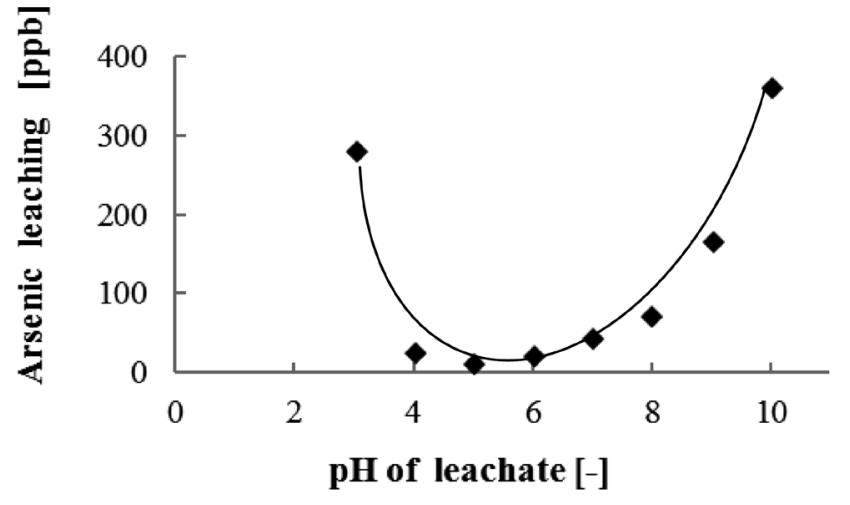

Fig. 1 Leaching concentration of arsenic from the red mud at different $\mathrm{pH}$ conditions.

$2.5 \mathrm{ppb}$ (by $\mathrm{HCl}$ ) with the $\mathrm{pH}$ of the leachate approximately corresponding to $6.1-6.3$. This constitutes significantly low As leaching when compared with the upper limit $(10 \mu \mathrm{g} / \mathrm{L})$ of the environmental criteria in Japan with respect to As leaching concentration.

The As leaching with the addition of $\mathrm{H}_{2} \mathrm{SO}_{4}$ or $\mathrm{HCl}\left(\mathrm{H}^{+}\right.$ $(\mathrm{mM})$ and red mud (g): $1.5 \mathrm{mM} / \mathrm{g}$ ) was significantly lower than that with the addition of Fe (III) ions. This was attributed to the addition of inorganic acids that cause a significant amount of $\mathrm{Fe}$ and $\mathrm{Al}$ ions to be released from the red mud, and the As in red mud could react with $\mathrm{Fe} / \mathrm{Al}$ ions in the process of mixing and placing in air to form insoluble compounds at a $\mathrm{pH}$ of 4 . Although the weakly acidic condition was advantageous for As adsorption, it did not reduce As leaching to the forementioned extremely low level. Thus, the formation of insoluble arsenic compounds is the main reason why As was successfully stabilized. The use of inorganic acids to dispose of As-containing red mud is an effective and stable method to stabilize As. Additionally, with respect to the viewpoint of the best stabilization effect, the addition of inorganic acid is a better proposition than the addition of $\mathrm{Fe}$

Table 3 Arsenic leaching concentration from the red mud with the addition of inorganic acids.

\begin{tabular}{lcccc}
\hline \hline Matrices composition & Concentration of acids [M] & Volume [mL] & Arsenic leaching [ppb] & pH of leachate [-] \\
\hline 2.0 g Red mud + $\mathrm{HCl}$ & 2.00 & 0.50 & 16.9 & 7.6 \\
& 2.00 & 1.00 & 9.2 & 6.3 \\
& 2.00 & 1.50 & 2.5 & 6.1 \\
\hline $2.0 \mathrm{~g}$ Red mud $+\mathrm{H}_{2} \mathrm{SO}_{4}$ & 2.00 & 2.00 & 7.1 & 4.7 \\
& 0.50 & 1.50 & 13.2 & 6.9 \\
& 1.00 & 1.50 & 1.6 & 6.3 \\
& 1.50 & 1.50 & 28.5 & 4.2 \\
\hline
\end{tabular}




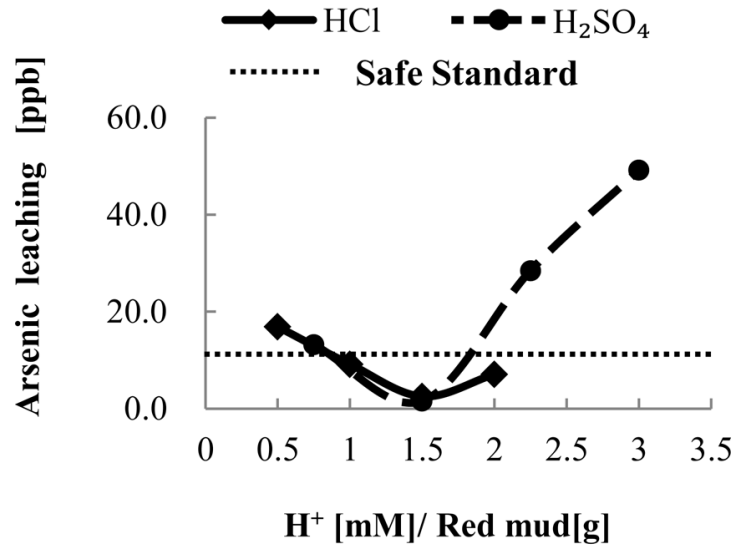

Fig. 2 Arsenic leaching concentration at different ratio of $\mathrm{H}^{+}[\mathrm{mM}] /$ red mud [g].

ions.

Additionally, $500 \mathrm{~g}$ red mud was tested at different ratios of the content of $\mathrm{H}^{+}(\mathrm{mM})$ and red mud $(\mathrm{g})$ with $\mathrm{H}_{2} \mathrm{SO}_{4}$. The results are listed in Table 4. In a manner similar to the results shown in Fig. 2, when the ratio of $\mathrm{H}^{+}(\mathrm{mM})$ and red mud $(\mathrm{g})$ is close to $1.5 \mathrm{mM} / \mathrm{g}$, then leaching concentrations of As are low $(3-5 \mathrm{ppb})$, and the $\mathrm{pH}$ of leachates approximately corresponded to $5-6$.

The alkali substance remaining in red mud influences the formation of insoluble arsenic compound and increases As leaching, and thus it is necessary to ensure that the ratio of $\mathrm{H}^{+}(\mathrm{mM})$ and red mud $(\mathrm{g})$ exceeds $1.2 \mathrm{mM} / \mathrm{g}$. A few carbonates were present in the red mud, and therefore the addition of acids created a significant amount of $\mathrm{CO}_{2}$ gas. In mixing the operation, red mud became ropy and was difficult to mix. After $24 \mathrm{~h}$, several holes appeared on the surface of the red mud, and a few transparent threadlike or white crystals separated out in the surface of red mud. This was different from
$\mathrm{H}_{2} \mathrm{SO}_{4}$ because only small crystals were created when $\mathrm{HCl}$ was added. This crystal was the same as those that appeared when $\mathrm{Fe}_{2}\left(\mathrm{SO}_{4}\right)_{3}$ was added to the red mud. The crystals were analyzed through SEM, EDX, and XRD (not shown here). The results revealed that crystals almost corresponded to disodium sulfate $\left(\mathrm{Na}_{2} \mathrm{SO}_{4}\right)$, which was considered relative to the $\mathrm{Fe}_{2}\left(\mathrm{SO}_{4}\right)_{3}$ or $\mathrm{H}_{2} \mathrm{SO}_{4}$ that was added.

In the SEM images (Fig. 3), large amounts of amorphous substances are evidently observed in the original dried red mud. On account of the high $\mathrm{pH}$ condition, it was speculated that a small amount of amorphous substance observed in the original red mud corresponded to hydroxides of $\mathrm{Fe} / \mathrm{Al}$ or ferrihydrite. With respect to the addition of Fe (III) ions, the $\mathrm{pH}$ of red mud changed to neutral, and the amount of amorphous substance was relatively low (as shown in B of Fig. 3). As shown in C and D of Fig. 3, the surface shapes are the same as those in the original dried red mud. Although the $\mathrm{pH}$ condition changed when acids were added, the amorphous substances remained as the main visible substances in the SEM images.

Stable arsenic compounds potentially generated in the red mud by the addition of Fe (III) ions or inorganic acids

The XRD analysis results of resultants in the simulation test are shown in Figs. 4-6. In the condition of $\mathrm{Fe}^{3+}: \mathrm{As}^{5+}=$ 20:1 (Fig. 4), with respect to the hydroxide of Fe, the main content corresponded to a high proportion in the resultants because of the Fe hydrolysis at $\mathrm{pH} 4$. Conversely, several insoluble $\mathrm{Fe}$-As compounds were also detected in this resultant and included pharmacosiderite $\left(\mathrm{Fe}_{4}\left(\mathrm{AsO}_{4}\right)_{3}(\mathrm{OH})_{4} \cdot 5 \mathrm{H}_{2} \mathrm{O}\right)$, iron arsenate $\left(\mathrm{Fe}_{2} \mathrm{As}_{4} \mathrm{O}_{12}\right)$, karibibite $\left(\mathrm{Fe}_{2} \mathrm{As}_{4} \mathrm{O}_{9}\right)$, and iron hydrogen arsenate $\left(\mathrm{FeHAsO}_{4}\right)$. Pharmacosiderite is insoluble and important in many environments to control the mobil-

Table 4 Arsenic leaching concentrations from $500 \mathrm{~g}$ red mud by the addition of $\mathrm{H}_{2} \mathrm{SO}_{4}$.

\begin{tabular}{|c|c|c|c|c|c|c|c|}
\hline Red mud [g] & $\mathrm{H}_{2} \mathrm{SO}_{4}[\mathrm{M}]$ & Volume [mL] & $\begin{array}{l}\text { Total of } \mathrm{H}^{+} \\
{[\mathrm{mM}]}\end{array}$ & $\begin{array}{c}\text { Ratio of } \\
\mathrm{H}^{+}[\mathrm{mM}] / \\
\text { red mud }[\mathrm{g}]\end{array}$ & $\begin{array}{c}\mathrm{pH} \text { of mixture } \\
{[-]}\end{array}$ & $\begin{array}{c}\text { Arsenic } \\
\text { leaching [ppb] }\end{array}$ & $\begin{array}{c}\mathrm{pH} \text { of } \\
\text { leachate [-] }\end{array}$ \\
\hline \multirow[t]{8}{*}{500} & 1.20 & 120 & 288 & 0.58 & 5 & 35.4 & 7.0 \\
\hline & 1.50 & & 360 & 0.72 & 5 & 29.8 & 7.0 \\
\hline & 1.80 & & 432 & 0.86 & $4-5$ & 35.9 & 6.8 \\
\hline & 2.00 & & 480 & 0.96 & $4-5$ & 13.2 & 6.6 \\
\hline & 2.30 & & 552 & 1.10 & $4-5$ & 6.8 & 6.8 \\
\hline & 2.50 & & 600 & 1.20 & $4-5$ & 9.8 & 6.6 \\
\hline & 3.00 & & 720 & 1.44 & 4 & 4.5 & 5.7 \\
\hline & 3.50 & & 840 & 1.68 & 4 & 3.0 & 5.0 \\
\hline
\end{tabular}




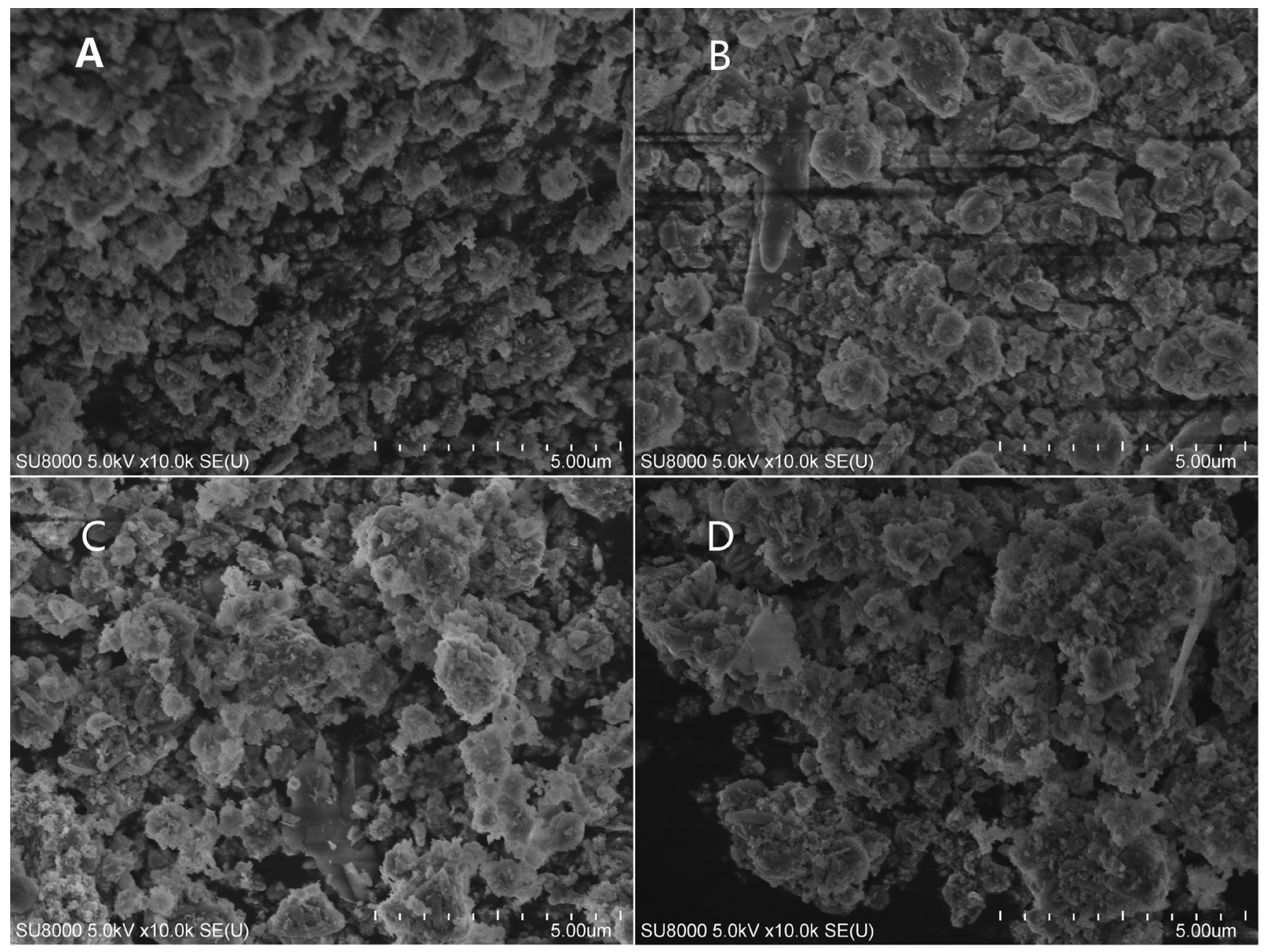

Fig. 3 SEM images: A) red mud, B) red mud disposed with Fe (III) ions, C) red mud disposed with $\mathrm{H}_{2} \mathrm{SO}_{4}$ and D) red mud disposed with $\mathrm{HCl}$.

ity of As [30]. Additionally, $\mathrm{FeHAsO}_{4}$ exhibits a very low solubility that is even lower than that of scorodite [31]. The formation of karibibite was also advantageous to As stabilization as reported in previous studies [22]. Other stable compounds, such as unnamed mineral $\left(\mathrm{FeAsO}_{4}\right)$ and diiron tris (arsenato) arsenate $\left(\mathrm{Fe}_{2}\left(\mathrm{As}\left(\mathrm{AsO}_{4}\right)_{3}\right)\right)$, were also generated in this resultant and possessed a low solubility that was the same as iron arsenate [32]. In the red mud, the As and Fe (III) ions potentially formed the Fe-As insoluble compounds, and this was considered responsible for the stabilization of As.

In the condition of $\mathrm{SO}_{4}{ }^{2-}: \mathrm{Fe}^{3+}: \mathrm{Al}^{3+}: \mathrm{As}^{5+}=33: 10: 10: 1$ (Fig. 5), the main contents corresponded to hydroxide and oxides of Fe and Al. A few new insoluble Al-As compounds also generated in addition to the formation of diiron tris (arsenato) arsenate, karibibite, and iron hydrogen arsenate. As reported in previous studies, aluminum arsenate $\left(\mathrm{Al}\left(\mathrm{AsO}_{4}\right)\right)$ is a stable arsenic compound easily generated in the presence of $\mathrm{Al}^{3+}$ [33]. Furthermore, the newly generated compound also included aluminum arsenate hydrate $\left(\mathrm{AlAs}_{3} \mathrm{O}_{9} \cdot 5 \mathrm{H}_{2} \mathrm{O}\right)$, which corresponds to an amorphous aluminum arsenate. There is a paucity of studies on $\mathrm{AlAs}_{3} \mathrm{O}_{9} \cdot 5 \mathrm{H}_{2} \mathrm{O}$ although studies examined analogs including $\mathrm{AlAsO}_{4} \cdot 3.5 \mathrm{H}_{2} \mathrm{O}$ and $\mathrm{AlAsO}_{4} \cdot 2 \mathrm{H}_{2} \mathrm{O}$ with low solubility albeit higher than that of scorodite $\left(\mathrm{FeAsO}_{4} \cdot 2 \mathrm{H}_{2} \mathrm{O}\right)$ [34]. When $\mathrm{H}_{2} \mathrm{SO}_{4}$ was added into the red mud, $\mathrm{Fe}^{3+}$ and $\mathrm{Al}^{3+}$ ions released from red mud could potentially react with As and form the Fe-As/ Al-As insoluble compounds, and this contributed to the stabilization of As in the red mud.

In the condition of $\mathrm{Cl}^{-}: \mathrm{Fe}^{3+}: \mathrm{Al}^{3+}: \mathrm{As}^{5+}=66: 10: 10: 1$ (Fig.6), the main substances included iron oxide hydroxide chloride ( $\left.\mathrm{FeO}(\mathrm{OH}) \mathrm{Cl}_{0.227}\right)$, aluminum oxide $\left(\mathrm{Al}_{2} \mathrm{O}_{3}\right)$, and iron oxide $\left(\mathrm{Fe}_{2} \mathrm{O}_{3}\right)$. Several amorphous substances appeared with respect to the existence of high amounts of $\mathrm{Cl}^{-}$. This is different from the As compounds that appear above since the 


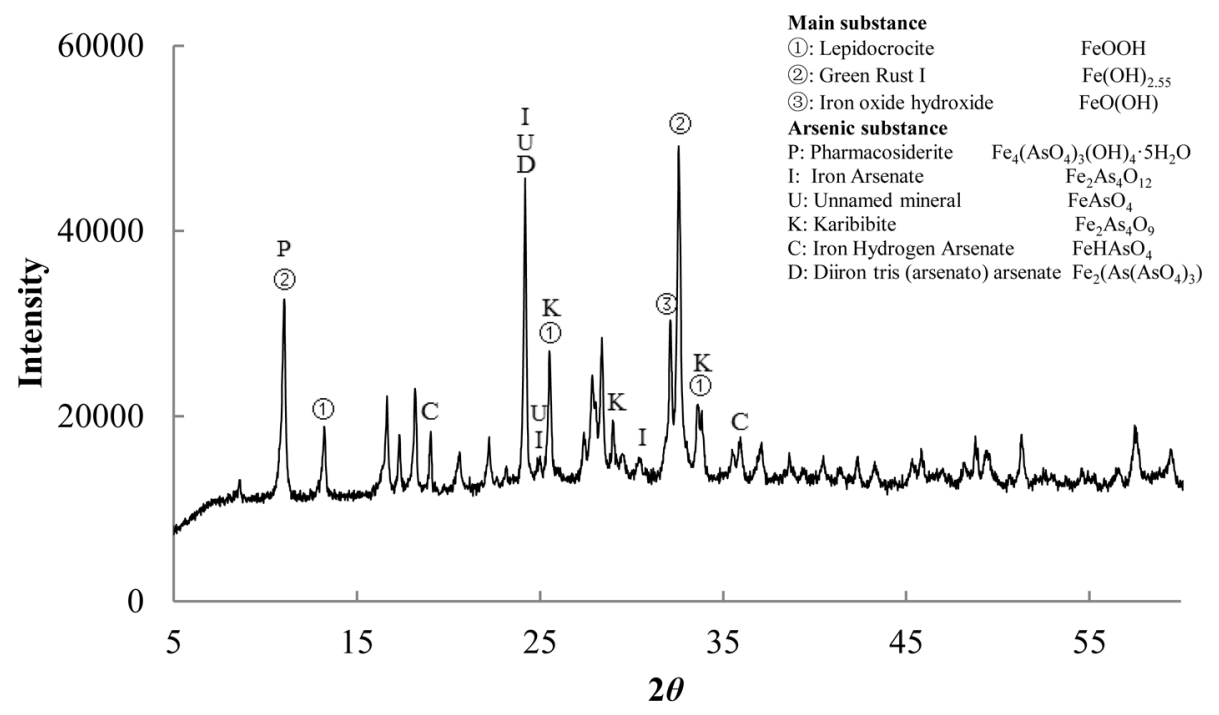

Fig. 4 Insoluble arsenic compound generated upon adding $\mathrm{Fe}^{3+}$.

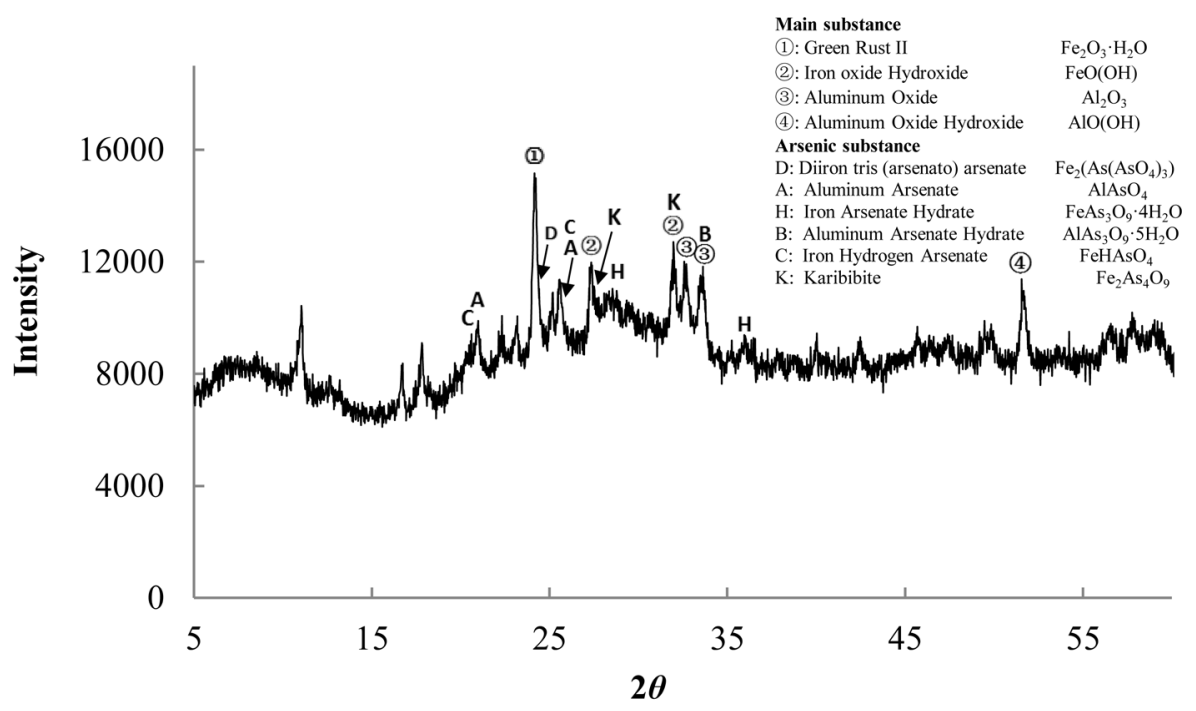

Fig. 5 Insoluble arsenic compound generated upon adding $\mathrm{H}_{2} \mathrm{SO}_{4}$.

new compound, parascorodite $\left(\mathrm{FeAsO}_{4} \cdot 2 \mathrm{H}_{2} \mathrm{O}\right)$, mansfieldite $\left(\mathrm{AlAsO}_{4} \cdot 2 \mathrm{H}_{2} \mathrm{O}\right)$, and aluminum arsenic (AlAs), were detected in the resultant. Parascorodite was metastable with respect to scorodite, which possessed the same chemical formula [35]. However, aluminum arsenic was unstable in water [36]. Mansfieldite was more reactive when compared with scorodite, and it was not a satisfactory carrier for the fixation of As in the environment [37]. In contrast, given the high amounts of amorphous substances, crystallinity of the As compound was not good and only a few insoluble As compounds generated. It was possible that when $\mathrm{HCl}$ was added into the red mud in the presence of many $\mathrm{Cl}^{-}$, the $\mathrm{Fe}^{3+}$ and $\mathrm{Al}^{3+}$ ions released from red mud were surrounded by $\mathrm{Cl}^{-}$to form coordination compounds such as $\left[\mathrm{FeCl}_{4}\right]^{-}$and $\left[\mathrm{AlCl}_{4}\right]^{-}[38,39]$. This potentially influenced the stabilization of As. Hence, it is preferable to use $\mathrm{H}_{2} \mathrm{SO}_{4}$ as opposed to $\mathrm{HCl}$ to dispose the red mud from a safety viewpoint.

From the XRD analysis, both the added Fe (III) ions and inorganic acids generate insoluble As compounds in the red mud. In the long-term stability test, after exposure to the air for 7, 30, 60, and $90 \mathrm{~d}$, As leaching concentrations from the red mud disposed by Fe (III) ions and inorganic acids are shown in Figs. 7 and 8.

The results indicated that As leaching was limited at a suf- 


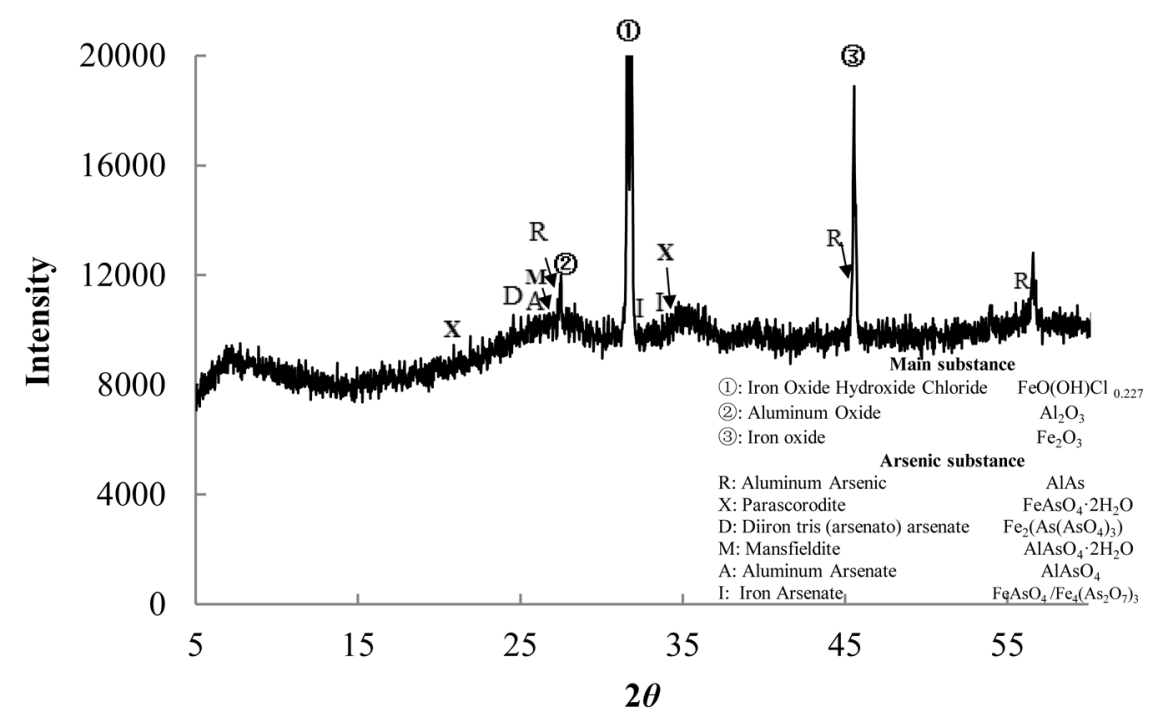

Fig. 6 Insoluble arsenic compound generated upon adding $\mathrm{HCl}$.

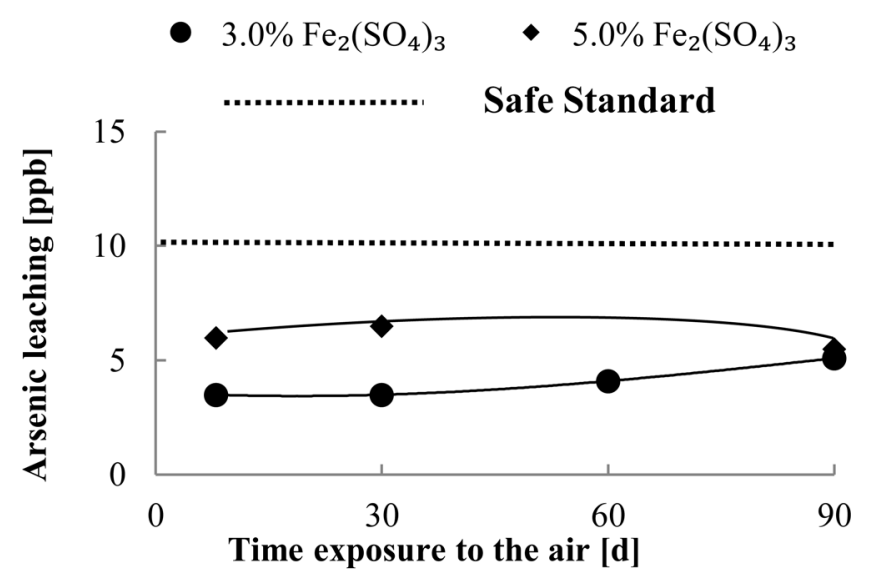

Fig. 7 Stability of arsenic in red mud disposed by Fe (III) ions.

ficient low level that approximately corresponded to $4-6$ ppb by $3-5 \% \mathrm{Fe}_{2}\left(\mathrm{SO}_{4}\right)_{3}$ and $2-5$ ppb by $\mathrm{H}_{2} \mathrm{SO}_{4}$ and $\mathrm{HCl}$ in the long-term stability test, and this is significantly lower than the environmental criteria $(10 \mu \mathrm{g} / \mathrm{L})$.

It was confirmed that the effect of As stabilization in the above operation was stable and that the red mud disposed was safe for recycling. Additionally, after mixing with inorganic acids, the concentration of $\mathrm{Fe}$ and $\mathrm{Al}$ ions released immediately from red mud were about 1.16 and $1.06 \mathrm{ppm}$ (leaching solution determined by AAS). And after the 90-d exposure in the air, the concentration of $\mathrm{Fe}$ and $\mathrm{Al}$ ions released from red mud were about 0.56 and $0.22 \mathrm{ppm}$ (leaching solution determined by AAS). This decrease suggested that Fe and

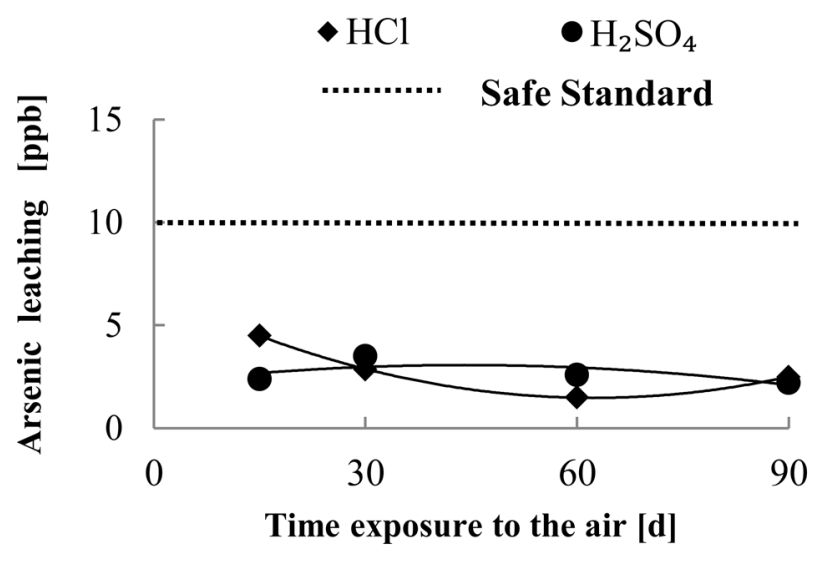

Fig. 8 Stability of arsenic in red mud disposed by $\mathrm{H}_{2} \mathrm{SO}_{4}$ and $\mathrm{HCl}$.

$\mathrm{Al}$ ions released from red mud at the beginning underwent coprecipitation that could adsorb As or formed the insoluble Fe-As and Al-As compounds in the exposure. With the addition of acids, the use of $\mathrm{Fe}$ and $\mathrm{Al}$ ions released from the red mud to stabilize As was better than the addition of $\mathrm{Fe}$ (III) ions from the viewpoint of the effect of As stabilization. Due to the negative influence of $\mathrm{Cl}^{-}$as discussed above, the addition of $\mathrm{H}_{2} \mathrm{SO}_{4}$ to dispose the red mud was more stable. Furthermore, acid addition was also suitable for a mixing operation in industrial treatment. However, with respect to the lost carbonate, red mud experienced a mass decrease and generated a high amount of $\mathrm{CO}_{2}$. 


\section{CONCLUSIONS}

This study involved investigating methods to stabilize As in red mud by the addition of $\mathrm{Fe}$ (III) ions, $\mathrm{H}_{2} \mathrm{SO}_{4}$, and $\mathrm{HCl}$. The addition of $3-5 \% \mathrm{Fe}_{2}\left(\mathrm{SO}_{4}\right)_{3}$ or the use of inorganic acids (ratio of $\mathrm{H}^{+}(\mathrm{mM}) /$ red mud $\left.(\mathrm{g}) \approx 1.5\right)$ to release Fe (III) and $\mathrm{Al}$ (III) ions in red mud controls As solubility at approximately $2-6 \mu \mathrm{g} / \mathrm{L}$ for several months, and this satisfies the requirement of the Environment Agency Notification 18 (less than $10 \mu \mathrm{g} / \mathrm{L}$ ) in Japan. Additionally, the $\mathrm{pH}$ of red mud also decreased to neutral, and this could be used as roadbed material or as other materials safely. The main reason for As stabilization in the red mud corresponded to the formation of insoluble Fe-As and Al-As compounds at $\mathrm{pH}$ 4. In this study, it was a new viewpoint to add Fe which was the main substance of red mud to stabilize As. Though it was very different from other stabilization of waste, it has a high effect on As stabilization. The XRD analysis indicated that the generated stable As compounds included pharmacosiderite, iron arsenate, iron hydrogen arsenate, aluminum arsenate, and aluminum arsenate hydrate, which were considered responsible for the low As leaching. Moreover, the results revealed that the presence of high amounts of $\mathrm{Cl}^{-}$negatively influenced the formation of insoluble As compounds, and thus the use of $\mathrm{HCl}$ was not an appropriate method to dispose the red mud. As opposed to Fe (III) ions, the use of $\mathrm{H}_{2} \mathrm{SO}_{4}$ is a better method to stabilize As in the red mud from the viewpoint of a long-term As stabilization effect.

\section{REFERENCES}

[1] Power G, Gräfe M, Klauber C: Bauxite residue issues: I. Current management, disposal and storage practices. Hydrometallurgy, 108(1-2), 33-45, 2011. doi:10.1016/j. hydromet.2011.02.006

[2] Meyer FM: Availability of Bauxite Reserves. Nat. Resour. Res., 13(3), 161-172, 2004. doi:10.1023/ B:NARR.0000046918.50121.2e

[3] Liu W, Yang J, Xiao B: Review on treatment and utilization of bauxite residues in China. Int. J. Miner. Process., 93(3-4), 220-231, 2009. doi:10.1016/j.minpro.2009.08.005

[4] Gräfe M, Power G, Klauber C: Bauxite residue issues: III. Alkalinity and associated chemistry. Hydrometallurgy, 108(1-2), 60-79, 2011. doi:10.1016/j.hydromet.2011.02.004

[5] Brunori C, Cremisini C, Massanisso P, Pinto V, Torricelli L: Reuse of a treated red mud bauxite waste: stud- ies on environmental compatibility. J. Hazard. Mater., 117(1), 55-63, 2005. doi:10.1016/j.jhazmat.2004.09.010 PMID:15621353

[6] Klebercz O, Mayes WM, Ánton AD, Feigl V, Jarvis AP, Gruiz K: Ecotoxicity of fluvial sediments downstream of the Ajka red mud spill, Hungary. J. Environ. Monit., 14(8), 2063-2071, 2012. PMID:22772744

[7] Lopes G, Guilherme LRG, Costa ETS, Curi N, Penha HGV: Increasing arsenic sorption on red mud by phosphogypsum addition. J. Hazard. Mater., 262(8), 1196-1203, 2013. doi:10.1016/j.jhazmat.2012.06.051 PMID:22795841

[8] Mayes WM, Jarvis AP, Burke IT, Walton M, Feigl V, Klebercz O, Gruiz K: Dispersal and attenuation of trace contaminants downstream of the Ajka bauxite residue (red mud) depository failure, Hungary. Environ. Sci. Technol., 45(12), 5147-5155, 2011. doi:10.1021/ es200850y PMID:21591764

[9] Ruyters S, Mertens J, Vassilieva E, Dehandschutter B, Poffijn A, Smolders E: The red mud accident in Ajka (Hungary): plant toxicity and trace metal bioavailability in red mud contaminated soil. Environ. Sci. Technol., 45(4), 1616-1622, 2011. doi:10.1021/es104000m PMID:21204523

[10] Burke IT, Mayes WM, Peacock CL, Brown AP, Jarvis AP, Gruiz K: Speciation of arsenic, chromium, and vanadium in red mud samples from the Ajka spill site, Hungary. Environ. Sci. Technol., 46(6), 3085-3092, 2012. doi:10.1021/es3003475 PMID:22324637

[11] Mohan D, Pittman CU Jr: Arsenic removal from water/ wastewater using adsorbents-A critical review. $J$. Hazard. Mater., 142(1-2), 1-53, 2007. doi:10.1016/j. jhazmat.2007.01.006 PMID:17324507

[12] Qu D, Wang J, Hou D, Luan Z, Fan B, Zhao C: Experimental study of arsenic removal by direct contact membrane distillation. J. Hazard. Mater., 163(2-3), 874-879, 2009. doi:10.1016/j.jhazmat.2008.07.042 PMID:18783884

[13] Chen YN, Chai LY, Shu YD: Study of arsenic(V) adsorption on bone char from aqueous solution. $J$. Hazard. Mater., 160(1), 168-172, 2008. doi:10.1016/j. jhazmat.2008.02.120 PMID:18417278

[14] Wickramasinghe S, Han B, Zimbron J, Shen Z, Karim $\mathrm{MN}$ : Arsenic removal by coagulation and filtration: comparison of groundwaters from the United States and Bangladesh. Desalination, 169(3), 231-244, 2004. doi:10.1016/S0011-9164(04)00530-2 
[15] Mondal P, Majumder CB, Mohanty B: Laboratory based approaches for arsenic remediation from contaminated water: Recent developments. J. Hazard. Mater., 137(1), 464-479, 2006. doi:10.1016/j.jhazmat.2006.02.023 PMID:16616812

[16] Waychunas GA, Rea BA, Fuller CC, Davis JA: Surface chemistry of ferrihydrite: Part 1. EXAFS studies of the geometry of coprecipitated and adsorbed arsenate. Geochim. Cosmochim. Acta, 57(10), 2251-2269, 1993. doi:10.1016/0016-7037(93)90567-G

[17] Sherman DM, Randall SR: Surface complexation of arsenic(V) to iron(III) (hydr)oxides: structural mechanism from ab initio molecular geometries and EXAFS spectroscopy. Geochim. Cosmochim. Acta, 67(22), 4223-4230, 2003. doi:10.1016/S0016-7037(03)00237-0

[18] Fendorf S, Eick MJ, Grossl P, Sparks DL: Arsenate and chromate retention mechanisms on goethite. 1. Surface structure. Environ. Sci. Technol., 31(2), 315-320, 1997. doi:10.1021/es950653t

[19] Lenoble V, Bouras O, Deluchat V, Serpaud B, Bollinger JC: Arsenic adsorption onto pillared clays and iron oxides. J. Colloid Interface Sci., 255(1), 52-58, 2002. doi:10.1006/jcis.2002.8646 PMID:12702367

[20] Langmuir D, Mahoney J, Rowson J: Solubility products of amorphous ferric arsenate and crystalline scorodite $\left(\mathrm{FeAsO}_{4} \cdot 2 \mathrm{H}_{2} \mathrm{O}\right)$ and their application to arsenic behavior in buried mine tailings. Geochim. Cosmochim. Acta, 70(12), 2942-2956, 2006. doi:10.1016/j. gca.2006.03.006

[21] Jia YF, Demopoulos GP, Chen N, Cutler JN, Jiang DT: Preparation, characterization and solubilities of adsorbed and co-precipitated iron (III)-arsenate solids. In: Young C, Alfantazi A, Anderson C, James A, Dreisinger D, Harris B (eds.): Electrometallurgy and Environmental Hydrometallurgy, Volume 2, John Wiley \& Sons, Hoboken, NJ, USA, pp.1923-1935, 2013.

[22] Paktunc D, Dutrizac J, Gertsman V: Synthesis and phase transformations involving scorodite, ferric arsenate and arsenical ferrihydrite: Implications for arsenic mobility. Geochim. Cosmochim. Acta, 72(11), 2649-2672, 2008. doi:10.1016/j.gca.2008.03.012

[23] Fernández-Martínez A, Cuello GJ, Johnson MR, Bardelli F, Román-Ross G, Charlet L, Turrillas X: Arsenate incorporation in gypsum probed by neutron, $\mathrm{X}$-ray scattering and density functional theory modeling. J. Phys. Chem. A, 112(23), 5159-5166, 2008. doi:10.1021/jp076067r PMID:18491845
[24] Zhang D, Yuan Z, Wang S, Jia Y, Demopoulos GP: Incorporation of arsenic into gypsum: Relevant to arsenic removal and immobilization process in hydrometallurgical industry. J. Hazard. Mater., 300, 272-280, 2015. doi:10.1016/j.jhazmat.2015.07.015 PMID:26188870

[25] Environment Agency: Notification No.19. Environment Agency, Tokyo, Japan.

[26] Environment Agency: Notification No.18. Environment Agency, Tokyo, Japan.

[27] Lin J, Chen N, Nilges MJ, Pan Y: Arsenic speciation in synthetic gypsum $\left(\mathrm{CaSO}_{4} \cdot 2 \mathrm{H}_{2} \mathrm{O}\right)$ : A synchrotron XAS, single-crystal EPR, and pulsed ENDOR study. Geochim. Cosmochim. Acta, 106, 524-540, 2013. doi:10.1016/j.gca.2012.12.019

[28] Ropp RC: Encyclopedia of the Alkaline Earth Compounds. Elsevier B.V, Amsterdam, The Netherlands, pp. 302-304, 2013.

[29] Mamindy-Pajany Y, Hurel C, Marmier N, Roméo M: Arsenic (V) adsorption from aqueous solution onto goethite, hematite, magnetite and zero-valent iron: Effects of $\mathrm{pH}$, concentration and reversibility. Desalination, 281, 93-99, 2011. doi:10.1016/j.desal.2011.07.046

[30] Drahota P, Filippi M: Secondary arsenic minerals in the environment: A review. Environ. Int., 35(8), 1243-1255, 2009. doi:10.1016/j.envint.2009.07.004 PMID:19665230

[31] Papassiopi N, Vaxevanidou K, Paspaliaris I: Investigating the use of iron reducing bacteria for the removal of arsenic from contaminated soils. Water Air Soil Pollut. Focus, 3(3), 81-90, 2003. doi:10.1023/A:1023905128860

[32] Ahmed N, Mikail M, Saha DK: Mineralogical study of Sediment samples of Kachua, Chandpur district for investigation of arsenic bearing minerals. Journal of Bangladesh Academy of Sciences, 32(1), 1-12, 2008.

[33] Sharan B: A new modification of aluminum orthoarsenate. Acta Crystallogr., 12(11), 948-949, 1959. doi:10.1107/S0365110X59002729

[34] Le Berre JF, Cheng TC, Gauvin R, Demopoulos GP: Hydrothermal synthesis and stability evaluation of iron (III)-aluminum (III) arsenate solid solutions. Metall. Mater. Trans., B, Process Metall. Mater. Proc. Sci., 38(2), 159-166, 2007. doi:10.1007/s11663-007-9032-7

[35] Majzlan J, Drahota P, Filippi M, Grevel KD, Kahl WA, Plášil J, Boerio-Goates J, Woodfield BF: Thermodynamic properties of scorodite and parascorodite $\left(\mathrm{FeAsO}_{4} \cdot 2 \mathrm{H}_{2} \mathrm{O}\right)$, kaňkite $\left(\mathrm{FeAsO}_{4} \cdot 3.5 \mathrm{H}_{2} \mathrm{O}\right)$, and $\mathrm{FeAsO}_{4}$. Hydrometallurgy, 117-118, 47-56, 2012. doi:10.1016/j.hydromet.2012.02.002 
[36] McAllster AJ: The Al-As (Aluminum-Arsenic) system. Bulletin of Alloy Phase Diagrams, 5(6), 577-579, 1984. doi:10.1007/BF02868319

[37] Le Berre JF, Cheng TC, Gauvin R, Demopoulos GP: Hydrothermal synthesis and stability evaluation of mansfieldite in comparison to scorodite. Can. Metall. Q., 46(1), 1-9, 2007. doi:10.1179/cmq.2007.46.1.1

[38] Magini M, Radnai T: X-ray diffraction study of ferric chloride solutions and hydrated melt. Analysis of the iron (III)-chloride complexes formation. J. Chem. Phys., 71(11), 4255-4262, 1979. doi:10.1063/1.438233

[39] Sun HT, Sakka Y, Shirahata N, Gao H, Yonezawa T: Experimental and theoretical studies of photoluminescence from $\mathrm{Bi}_{8}{ }^{2+}$ and $\mathrm{Bi}_{5}{ }^{3+}$ stabilized by $\left[\mathrm{AlCl}_{4}\right]^{-}$in molecular crystals. J. Mater. Chem., 22(25), 12837-12841, 2012. doi:10.1039/c2jm30251a 